\title{
SOEP
}

SOEPpapers

SOEPpapers
on Multidisciplinary Panel Data Research

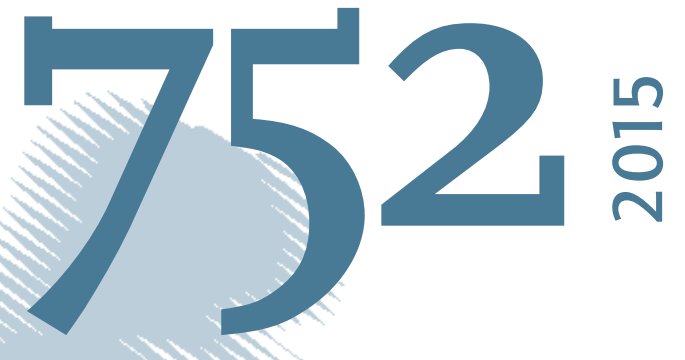

\section{Television Role Models and Fertility - Evidence from a Natural Experiment}

Peter Bönisch and Walter Hyll 
This series presents research findings based either directly on data from the German SocioEconomic Panel study (SOEP) or using SOEP data as part of an internationally comparable data set (e.g. CNEF, ECHP, LIS, LWS, CHER/PACO). SOEP is a truly multidisciplinary household panel study covering a wide range of social and behavioral sciences: economics, sociology, psychology, survey methodology, econometrics and applied statistics, educational science, political science, public health, behavioral genetics, demography, geography, and sport science.

The decision to publish a submission in SOEPpapers is made by a board of editors chosen by the DIW Berlin to represent the wide range of disciplines covered by SOEP. There is no external referee process and papers are either accepted or rejected without revision. Papers appear in this series as works in progress and may also appear elsewhere. They often represent preliminary studies and are circulated to encourage discussion. Citation of such a paper should account for its provisional character. A revised version may be requested from the author directly.

Any opinions expressed in this series are those of the author(s) and not those of DIW Berlin. Research disseminated by DIW Berlin may include views on public policy issues, but the institute itself takes no institutional policy positions.

The SOEPpapers are available at http://www.diw.de/soeppapers

\section{Editors:}

Jan Goebel (Spatial Economics)

Martin Kroh (Political Science, Survey Methodology)

Carsten Schröder (Public Economics)

Jürgen Schupp (Sociology)

Conchita D'Ambrosio (Public Economics)

Denis Gerstorf (Psychology, DIW Research Director)

Elke Holst (Gender Studies, DIW Research Director)

Frauke Kreuter (Survey Methodology, DIW Research Fellow)

Frieder R. Lang (Psychology, DIW Research Fellow)

Jörg-Peter Schräpler (Survey Methodology, DIW Research Fellow)

Thomas Siedler (Empirical Economics)

C. Katharina Spieß (Education and Family Economics)

Gert G. Wagner (Social Sciences)

ISSN: 1864-6689 (online)

German Socio-Economic Panel Study (SOEP)

DIW Berlin

Mohrenstrasse 58

10117 Berlin, Germany

Contact: Uta Rahmann | soeppapers@diw.de 


\title{
Television Role Models and Fertility - Evidence from a Natural Experiment
}

\author{
Peter Bönisch ${ }^{\S *^{+}}$ \\ and \\ Walter Hyll*
}

\begin{abstract}
In this paper we study the effect of television exposure on fertility. We exploit a natural experiment that took place in Germany after WWII. For topographical reasons, Western TV programs, which promoted one/no child families, could not be received in certain parts of East Germany. Using an IV approach, we find robust evidence that watching West German TV results in lower fertility. This conclusion is robust to alternative model specifications and data sets. Our results imply that individual fertility decisions are affected by role models or information about other ways of life promoted by media.
\end{abstract}

Keywords: Natural experiment; TV consumption; Fertility

JEL classification: C26; D12; J13; L82

$\S$ Corresponding Author

Martin-Luther-University Halle-Wittenberg

Große Steinstraße 73

06108 Halle

* Halle Institute for Economic Research (IWH) - Member of the Leibniz Association

Kleine Märkerstraße 8

D-06108 Halle (Saale)

${ }^{+}$NERA Economic Consulting Berlin 


\section{Introduction}

Many developed countries-especially European countries-have experienced a sharp decline in fertility over the last few decades, leading to a fertility rate below the reproduction level. In addition, most of these countries are characterized by aging populations and will be or already are confronted with a demographic development challenging their labor markets, welfare systems, and political institutions in several respects.

Fertility is affected by many factors ranging from the costs of having children (e.g. Mörk et al., 2013; Brewer et al., 2010; Milligan, 2005) to family friendly labor market policies (Kalwij 2010). Several scholars devote their research to the question of whether (higher) education influences fertility (e.g. Goldin and Katz, 2000; Davis, 2011). Jensen (2012) points to the role of labor market opportunities itself in affecting marriage and fertility decisions. Similarly, Del Bono et al. (2012) show that job displacement negatively affects the probability of having a child. Moreover, economic models explaining individual fertility decisions have recently been widened to account for factors beyond the classical investment and opportunity cost framework (see for example Becker and Lewis, 1973) such as neighborhood effects or income inequality (Kearney and Levine, 2014). For example, Li and Zhang (2009) study the external effect of household childbearing on the demand for children. Their findings suggest that the probability of a household having a second child decreases if the proportion of neighboring households with two children decreases. Likewise, Fernández and Fogli (2006) demonstrate that women's own personal experience and their culture - proxied by the total fertility rate in the parents’ country of origin - play a role in influencing their fertility.

In this paper, we contribute to the literature exploring the impact of environmental factors determining individual fertility decisions beyond the opportunity cost framework. In particular, we focus on reference group effects resulting from the exposure to role models and lifestyles transmitted via television, shaping individuals attitudes, preferences, and beliefs. For 
this undertaking, we take advantage of a unique natural experiment that took place in Germany after WWII. For topographical reasons, Western TV programs and their specific content regarding family role models and material aspirations could not be received in certain parts of East Germany. This quasi-experimental setup allows the identification of a causal relationship between TV exposure and fertility behavior in a developed country. We underpin our results by applying three different data sets on different levels of aggregation, namely the Statistical yearbooks of the GDR, data collected by the Central Institute of Youth Research, and the German Socio Economic Panel (SOEP).

The importance of TV for family role models and fertility behavior has largely been ignored in economic studies on the determinants of fertility although several papers in other fields show that television exposure affects attitudes and behavior, which might be relevant to fertility decisions as well. For example, Morgan and Rothschild (1983) analyze the effect of watching TV on gender role stereotypes. Holbert, Shah, and Kwak (2003) deal with opinions concerning women's rights stemming from prime time TV consumption, Becker (2004) analyzes the effects of television on adolescent girls' identity and body image, and Chong and La Ferrara (2009) explore the effect of geographical television expansion on divorce rates in Brazil. Recently, the impact of television exposure on fertility has attracted economists' attention. La Ferrara, Chong, and Duryea (2012) and Jensen and Oster (2009) suggest that television might play a central role in determining family structure, women's status, and fertility. As identification strategy La Ferrara, Chong, and Duryea (2012) make use of the different timing of entry of the main soap opera producer in Brazil. Similarly, Jensen and Oster (2009) exploit the introduction of cable television in India.

No evidence, however, exists on the impact of TV consumption on fertility in the developed world, in an environment where most development related policies affecting fertility , such as 
universal access to health and child care, electrification, and female labor market participation, have been in place for a long time.

We advance the existing literature in several ways. First, we provide additional evidence for the relationship between TV consumption and fertility. Second, we employ information on TV exposure at the individual level. That is, we rely on individual data on the actual frequency of watching TV while most seminal economic studies on this subject have had no information on individual TV consumption. Jensen and Oster (2009), for example, measure cable access in India at the village level. Similarly, La Ferrara, Chong, and Duryea (2012) and Chong and Ferrara (2009) use information on whether an area is covered by the signal of Rede Globo, the main soap opera producer in Brazil. Finally, we are the first showing a TV effect on fertility for a developed country, namely the German Democratic Republic (GDR).

The GDR was one of the world's biggest economies during the period under consideration, where-in comparison to industrializing or developing countries—-the demographic transition was completed. ${ }^{1}$ Within the GDR it is plausible to assume that variation in TV access is independent of several other determinants affecting fertility preferences. For example, infrastructure, female labor market participation, health care, income distribution, and the use of contraceptives had been well developed and homogeneous throughout the GDR. Therefore, our setting allows us to rule out that the introduction of TV is associated with other political, social, institutional, or economic changes that likely impact on fertility preferences (see Potter et al., 2002).

Our empirical identification strategy is close to a laboratory experiment: due to topographical variation assignment to treatment-in our case Western TV consumption-was random. This implies that differences in fertility behavior can be assigned to differences in the reception of

1 According to Heston, Summers, Aten (2009), based on GDP at current prices, the GDR was among the 20 largest countries in the world. 
Western TV programs. Our empirical results strongly suggest that fertility behavior is affected by lifestyles preferences and images presented on TV.

The rest of the paper is divided into five sections. In section 2, we provide some background on television in the divided Germany and describe the TV content broadcast on both sides of the Iron Curtain. Next, we discuss econometric issues and elaborate upon the natural experiment that permits the strengthening of the causal interpretation of our results. In Section 4 we discuss the main data employed. Estimation results and a number of robustness checks are presented in Section 5; we conclude in Section 6.

\section{Television in the Divided Germany}

In this section we start with the description of how television evolved in both parts of Germany after WWII. Afterwards, we discuss the empirical implementation of our hypothesis and demonstrate the validity of the underlying identifying assumptions.

Following WWII, Germany was divided into two countries. TV broadcasting developed differently on the two sides of the Iron Curtain that divided this formerly homogenous country. In West Germany, the United States, the United Kingdom, and France were instrumental in founding a BBC-like public broadcasting system; East Germany established its own TV stations based on the Soviet model.

In the GDR, state-controlled TV was employed for the purpose of indoctrination. ${ }^{2}$ In an economy of shortage, the communist regime promoted full employment of both men and women. To increase population size and, hence, the labor force, a two- to three-child policy was instituted. ${ }^{3}$ The policy was supported by investment in child care, financial support for families, housing subsidies, and promotion of the ideal family as consisting of many children

2 Actually, it was not the state, but the leading communist party SED, that controlled TV programming.

3 East German's constitution viewed marriage and family as the foundation of society. In 1966, an official family code became effective in which it was stated that the aim of marriage was to have children (§9 FGD). 
and employed and married women. Several studies (Pfau et al., 2010; Trültzsch, 2009) analyze how this family model was promoted on GDR television. For example, in an analysis of family series of the 1980s Trültzsch (2009) finds that all female characters are employed and bear the double burden of family and job. As in real life, employment is much valued by all. Leisure time is depicted as a scarce good. In addition to employment, family, including parenting, plays an important role. TV families have a high number of children (about four) and this is depicted in a positive light. Showing problems with the work-life balance is taboo. In TV series aired prior to the 1980s, the ideal GDR family—characterized by a large number of children—was even more evident (Pfau et al., 2010).

West German TV, which was not influenced by the state, aired completely different subject matters, information, and programs than those seen on East German TV. Western TV programs provided a view of a much wealthier and prettier world, and in the matter of family and gender stereotypes, the contrast between the two types of TV programming was severe and diametrically opposed. For example, an analysis of West German TV programs showed that children played a small part in the West German television world; less than 8 percent of the female characters had children (Weiderer, 1994). Even in family series, more than half of all main characters had no children (Weiderer and Faltenbacher, 1994). Similar results are found in Küchenhoff (1975) 15 years earlier. During the 1970s, most families on TV were depicted in a negative light, and seemed especially prone to quarreling. Several studies on Western TV shows aired during the period under consideration find that most women on TV were unmarried, young, appealing, and did not work; married women were depicted as maternalistic and as lacking sex appeal (Küchenhoff, 1975; Weiderer, 1994; and Weiderer and Faltenbacher, 1994). The labor participation rate among female characters never exceeded 50 percent; among married women, employment was less than 20 percent. At the same time, housework did not seem relevant and only very few women were shown engaged in household activities. 
Figure 1: Signal Strength of Western TV Stations in Eastern Germany (the German Democratic Republic, GDR)

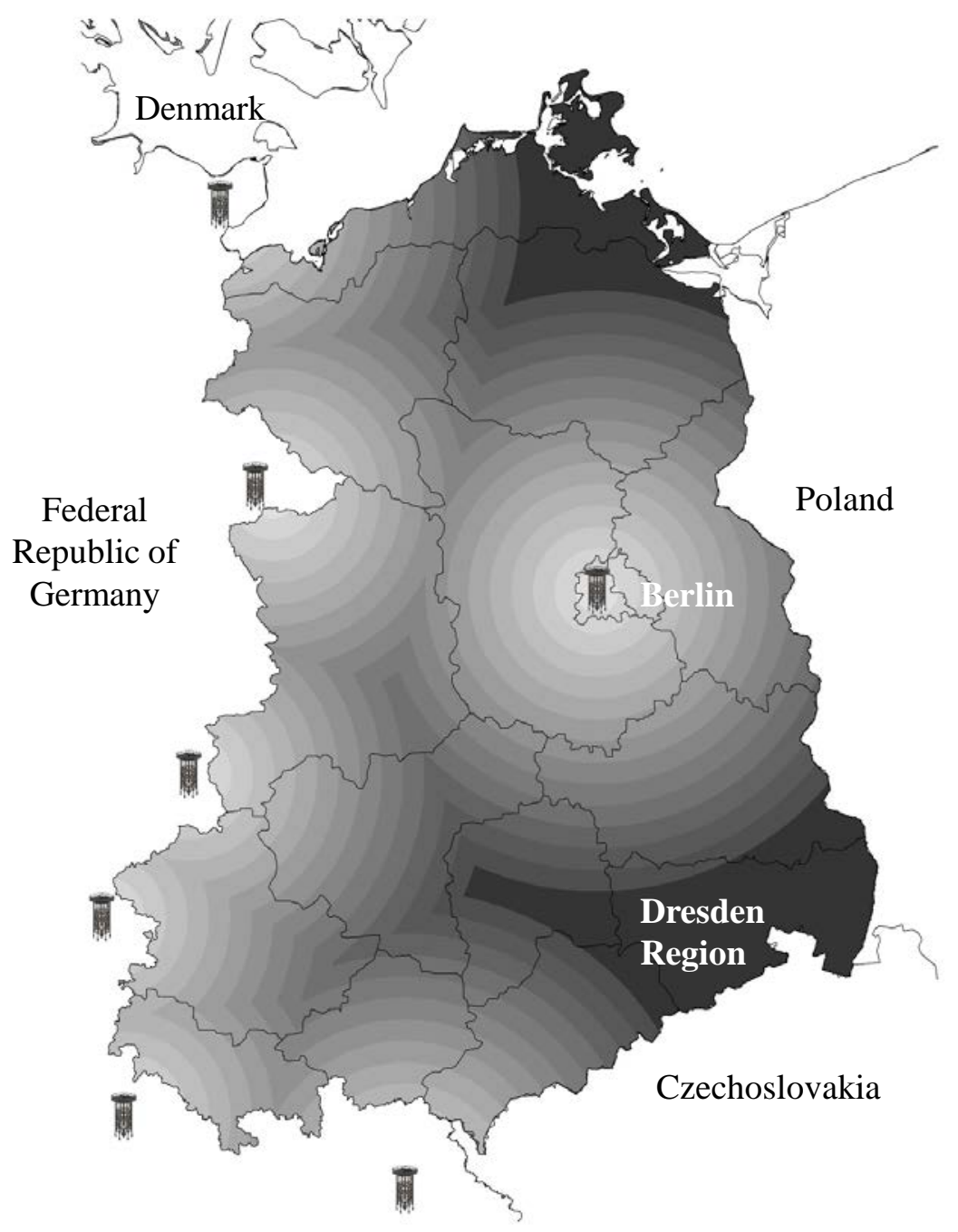

Note: Dark lines indicate administrative boundaries (Bezirksgrenzen) of the GDR. Black areas indicate dead spots for Western TV reception.

In the GDR, access to the state-controlled broadcasting service was ubiquitous. However, if possible, most GDR citizens watched Western TV. ${ }^{4}$ West Germany broadcasted to the East with the aims of providing uncensored information, generating pro-Western sentiment, and undermining public support for communism. To maximize availability of West German TV in

\footnotetext{
$4 \quad$ According to Wolle (1998, p. 71), each night East Germans “collectively emigrated” to West Germany in
} front of their TV sets. 
East Germany, several West German television broadcasting transmitters were placed next to the East German border.

What makes the situation described above a natural experiment for our undertaking is the fact that due to topographical variation, not all areas in the GDR were reached by Western broadcasting. Figure 1 shows the signal coverage of West German TV in the GDR, and illustrates that distance from the broadcasting towers located near the inner German border and West Berlin determines signal strength. Note, specifically, that the region around Dresden in the southern part of the GDR is a dead spot for Western TV. In the Northeast there is a second area without access to the West German TV signal; unfortunately, this area does not overlap with administrative region borders of the GDR, making it impossible to assign individuals to this particular area. ${ }^{5}$

In summary, we argue that Western TV promoted lifestyles in which having children is of little importance. Furthermore, West German television contributed to spread images of consumption-orientated lifestyles, which also increased material aspirations (Hyll and Schneider 2013). Bursztyn and Cantoni (forthcoming) also show that exposure to Western broadcasts affected the composition of consumption, biasing choices in favor of categories of goods with high intensity of pre-reunification advertisement. This is likely to have had a depressing effect on fertility levels (Becker, 1960). Given the impact of TV exposure on preferences, attitudes, and beliefs (Gerbner et al., 2002 or Shrum, Burroughs and Rindfleisch, 2005), we assume that the "transportation" of new values and ideas from West Germany altered priorities and fertility preferences in East Germany. Thus, we hypothesize that consumption of Western TV affects fertility behavior. We take advantage of the Cold War natural experiment previously described to identify the effect of Western TV on fertility. Kern

5 Note that in our sample no respondent resides in the northern region that comprises all "three" signal strengths. 
and Hainmueller (2009) and Hyll and Schneider (2013) use the same natural experiment to study the consequences of West German television on public support for the East German communist regime and on material aspirations, respectively.

\section{Empirical Strategy}

This part of the paper is organized in three subsections. First we describe the econometric techniques employed and second we thoroughly discuss the implicit identifying assumptions that render our empirical setup a natural experiment. Finally we present the data set on which our main results are based on.

\subsection{Econometrical Specification}

Our goal is to assess how lifestyles promoted by Western TV influence fertility behavior. Hence, the regression equation of interest for individual $i, i=1, \ldots, N$, is

$$
y_{i}=\gamma T V_{i}^{*}+\beta X_{i}+u_{i}
$$

where $y_{i}$ is the observed number of children explained by Western TV consumption, $T V_{i}^{*}$, and other individual and household characteristics $X_{i} \cdot \gamma$ and $\beta$ denote parameters and $u_{i}$ is an i.i.d. error term. According to our hypothesis, we expect $\gamma$ to have a negative sign.

Unobservable variables, however, might influence both TV and fertility behavior. For example, a preference for materialistic consumption goods could affect the observed number of children as well as the tendency to watch Western TV. Furthermore, individuals with a preference for a small number of children might be more inclined to watch Western TV. In these cases, an endogeneity problem arises.

We overcome this problem by taking an IV approach that exploits the natural variation in West German television exposure in East Germany. Western TV consumption, $T V_{i}$, is 
measured in ordinal units, ranging from never watching Western TV to daily consumption. That is, we observe

$$
T V_{i}=\left\{\begin{array}{lll}
0 & \text { if } & T V_{i}^{*} \leq \mu_{0} \\
1 & \text { if } & \mu_{0}<T V_{i}^{*} \leq \mu_{1} \\
\vdots & & \\
4 & \text { if } & \mu_{3}<T V_{i}^{*}
\end{array}\right.
$$

In a first step, we estimate the following ordered probit model using maximum likelihood,

(3) $T V_{i}^{*}=\eta D+\tau X_{i}+\varepsilon_{i}$,

where $D$ is a dummy variable indicating that an individual resides in the Dresden region. $X_{i}$ is set of exogenous control variables, $\eta$ and $\tau$ denote the associated parameters, and $\varepsilon_{i}$ is an i.i.d. error term.

In the second step, we insert the reduced-form prediction of Western TV consumption from Equation (3) into Equation (1). Now, the parameter of interest $\gamma$ in Equation (1) is identified by the Dresden region dummy.

To estimate Equation (1) we employ different econometric models so as to prove the robustness of our results with respect to different measures of fertility and the associated distributional assumptions. First, we estimate a probit model explaining the likelihood of having children given the set of control variables. Second, we assume a latent fertility preference and estimate an ordered probit model. Both models are estimated FIML assuming a bivariate normal distribution. Finally, we employ a poisson model to estimate the probability of having a certain number of children. ${ }^{6}$ In this case, we perform a LIML two-step maximum likelihood approach and correct the resulting variance using a bootstrap procedure

6 In this case, Equation (1) becomes $y_{i}=\exp \left(\gamma T V_{i}^{*}+\beta X_{i}+u_{i}\right)$. 
(for a discussion of sequential two-step m-estimation procedures see Cameron and Trivedi 2005).

\subsection{Identifying Assumptions}

Our empirical identification strategy crucially relies on the assumption that simply living in the region around Dresden does not explain fertility behavior (beyond the mere effect of Western TV consumption). That is, the residual of Equation (1) should be orthogonal to the Dresden region indicator. ${ }^{7}$

In what follows we show that living conditions which might affect fertility in the region around Dresden were very similar to conditions in the other regions of East Germany before and after treatment with Western TV. Figure 2 displays several region characteristics that could have an impact on fertility. The black dot refers to the Dresden region. Empty circles refer to the other 14 former GDR regions. By comparing the characteristics of 1987 with those of 1972 we are able to check our identifying assumption that regions do not systematically differ beyond unobserved variables neither before nor during Western TV treatment.

In 1972 consumption of Western TV was generally low for several reasons. In 1970 less than 70 percent of households had a TV set, compared to over 95 percent in 1987. More importantly, in the 1960s the GDR government prohibited Western TV and accompanied this by major campaigns to remove aerials pointing at the West. In 1971 political leadership changed and Walter Ulbricht was replaced by Erich Honecker. In subsequent years the relations between the GDR and West Germany were characterized by a policy of détente and

\footnotetext{
7 In a similar vein Kern and Hainmüller (2009) and Hyll and Schneider (2013) demonstrate that economic, political, and social conditions in the Dresden region did not systematically differ from conditions in the other regions of East Germany.
} 
the prohibition placed on watching of Western TV was eased, implying that Western TV became unofficially tolerated.

As can be seen in Figure 2, particularly the share of children in childcare, the female employment rate, the housing stock, and the number of beds in hospitals had been very homogeneous throughout the GDR and even converged during the period of consideration. While the number of marriages was almost identical in 1972 some drifts become apparent till 1987. Furthermore, residential mobility was extremely low throughout the GDR. Due to central planning, there was no conventional labor market and hence no labor mobility. Also, a shortage of housing further eliminated spatial sorting. On average, only about 0.7 percent of the population moved across region borders per year. Therefore, we can rule out that systematical migration from or to the region around Dresden occurred and that spatial sorting affects our results.

We test our assumption of homogeneous living conditions among GDR regions using a nonparametric estimator (alpha $=0.1$ ) for the 0.25 and the 0.75 quartiles of the unknown distribution. ${ }^{8}$ We find that the region around Dresden never falls below or above the 0.25 or 0.75 quartiles, respectively. This statistically underpins our reasoning outlined above. Regarding the variables depicted in Figure 2 the Dresden region was very similar to other East German regions. In line with the findings of Kern and Hainmueller (2009) and Hyll and Schneider (2013) this reflects the doctrine of democratic centralism aiming for a conformist society.

8 This test solely relies on the assumption of an ordered statistic and does not presume any particular distribution function. For further details on non-parametric tests see Büning and Trenkler (1994). 
Figure 2: Comparison of Fertility Related Indicators across Regions: 1972 vs. 1987

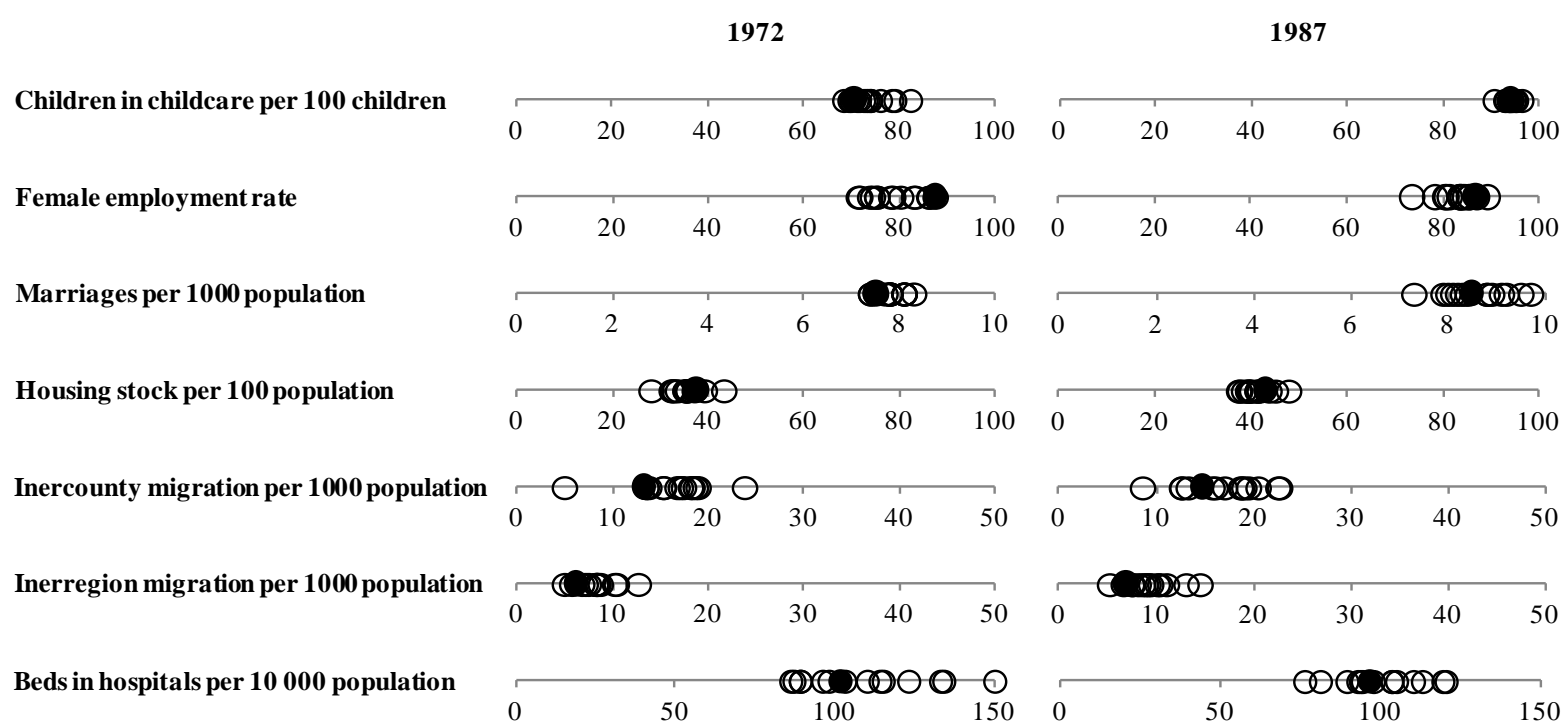

Notes: Black solid circles display values for the Dresden region; empty circles display values for the other regions. Statistical Yearbooks of the GDR, 1975 and 1990.

\subsection{Data}

Our main data set was conducted between the end of 1988 and the beginning of 1989. At that time, GDR was a stable communist country and no one expected its termination. We use formerly classified data collected by the Central Institute for Youth Research (the Zentralinstitut für Jugendforschung). ${ }^{9}$ The Central Institute produced many critical studies that were never allowed to be published. To ensure respondents' anonymity, questionnaires were conducted in group settings, were unmarked, and were collected in sealed urns. ${ }^{10}$

9 Zentralinstitut für Jugendforschung, Leipzig (n.d.): Political Climate and Social Conditions in the GDR 1988/1989. GESIS Data Archive, Cologne. ZA6008 Data file Version 1.0.0, http://dx.doi.org/10.4232/1.6008.

10 Such a procedure makes the data set credible even for the politically sensitive questions analyzed by Kern and Hainmueller (2009). For detailed description of the data-gathering process and the Central Institute, see Kern and Hainmueller (2009). Furthermore, we discuss this issue in more detail in section 4.2 of this paper and provide strong empirical evidence for the robustness of our results and the credibility of the data set used for our empirical analysis. 
Table 1: Description and Summary Statistics of Endogenous Variables

\begin{tabular}{|c|c|c|c|c|c|c|}
\hline \multicolumn{3}{|c|}{ Variable Definition } & \multicolumn{4}{|c|}{ Summary Statistics } \\
\hline \multirow[t]{2}{*}{ Variable } & \multicolumn{2}{|c|}{ Description/Item } & \multicolumn{2}{|c|}{ Control Group } & \multicolumn{2}{|c|}{ Treatment Group } \\
\hline & & & Observations & Share & Observations & Share \\
\hline \multirow{5}{*}{ CHILDREN } & \multirow{5}{*}{$\begin{array}{l}\text { number of } \\
\text { children }\end{array}$} & 0 & & 58.84 & & 62.81 \\
\hline & & 1 & & 21.46 & & 22.01 \\
\hline & & 2 & 396 & 16.92 & 1,272 & 13.52 \\
\hline & & 3 & & 2.27 & & 1.42 \\
\hline & & 4 & & 0.51 & & 0.24 \\
\hline \multirow{6}{*}{ TV } & \multirow{6}{*}{$\begin{array}{l}\text { frequency of } \\
\text { watching } \\
\text { Western TV }\end{array}$} & Never & & 69.71 & & 2.35 \\
\hline & & Rarely & & 13.67 & & 4.08 \\
\hline & & Once a week & & 1.88 & 117 & 2.43 \\
\hline & & Several times & & 9.65 & & 30.25 \\
\hline & & a week & & & & \\
\hline & & Daily & & 5.09 & & 60.89 \\
\hline
\end{tabular}

Our data set consists of 1,680 women, aged 15 to 50 . The mean age in our sample is 23.4 years and covers exactly the age cohorts relevant for our undertaking. ${ }^{11}$ We measure fertility behavior with the observed number of children. Individual consumption of Western TV is captured by answers to the question: "How often do you watch Western TV?” The possible responses were: “daily, several times a week, once a week, less often, never.”

As mentioned above, in contrast to previous studies, we use actual TV consumption to explain fertility behavior instead of mere access to TV signals and, hence, are able to instrument individual consumption behavior with exogenous topographical signal reception conditions.

11 According to the statistical yearbook of the GDR 1990, more than 99\% of all children were born to mothers aged 15 to 50. The average age of women who gave birth to a child in 1989 was about 24, which is approximately the average age in our sample. 
We assume that reported individual TV consumption is a suitable proxy for long-term individual TV consumption behavior. Given the very low geographical mobility in East Germany and the ubiquitous availability of TV sets, this is a reasonable assumption. ${ }^{12}$

In our data set respondents reside in one of eight regions, one of which, the region around Dresden, was not exposed to West German TV (see Figure 1) and, hence, constitutes the control group of our natural experiment; 398 women are from the Dresden region where only a very weak signal could be received, and only in fringe areas bordering other regions. Table 1 gives the summary statistics for the number of children and the frequency of watching Western TV for both groups. As expected, we find the share of respondents having less than two children to be higher in the treatment group while the opposite holds for the control group. The lower part of Table 1 shows that, as discussed above, due to topographical reasons the frequency of watching TV is much smaller within the control group than in the treatment group. In the Dresden region, about 5.09 percent of respondents watched West German TV daily, compared to 60.89 percent of respondents living in other regions. Consequently, watching Western TV and a dummy variable indicating residence in the Dresden region are strongly and negatively correlated at -0.76 , significant with a $p$-value of 0.0000 .

Table 2 provides summary statistics for the set of control variables used in our empirical analysis. We account for age, income, religion, marital status, partnership status, living in a rural or urban area, number of school years, whether a woman has graduated from school, and whether a woman is still in university or vocational training.

12 Already by 1980, each household had 1.05 TV sets (see Statistical Yearbook of the GDR 1990, p. 291). 
Table 2: Variable Definition and Descriptive Statistics of Control Variables

\begin{tabular}{|c|c|c|c|c|c|}
\hline \multicolumn{2}{|r|}{ Variable Definition } & \multicolumn{4}{|c|}{ Summary Statistic } \\
\hline \multirow[t]{2}{*}{ Variable } & \multirow[t]{2}{*}{ Description } & \multicolumn{2}{|c|}{ Control group } & \multicolumn{2}{|c|}{ Treatment group } \\
\hline & & Mean & Sd. & Mean & Sd. \\
\hline$\overline{\mathrm{AGE}}$ & age in years & 23.40 & 6.63 & 23.42 & 6.45 \\
\hline INCOME & monthly net income & 501.52 & 327.86 & 533.84 & 332.55 \\
\hline PARTNER & 1 if respondent lives together with her partner & 0.26 & 0.44 & 0.20 & 0.40 \\
\hline MARRIED & 1 if respondent is married & 0.33 & 0.47 & 0.33 & 0.47 \\
\hline RELIGIOUS & 1 if respondent believes in god & 0.16 & 0.37 & 0.14 & 0.35 \\
\hline RURAL & $\begin{array}{l}1 \text { if living in a village with at most } 2,000 \\
\text { inhabitant }\end{array}$ & 0.15 & 0.36 & 0.26 & 0.44 \\
\hline URBAN & $\begin{array}{l}1 \text { if living in a city of more than 50,000 } \\
\text { inhabitants }\end{array}$ & 0.43 & 0.5 & 0.35 & 0.48 \\
\hline EDUCATION & number of years in school & 10.00 & 0.94 & 10.06 & 0.48 \\
\hline TRAINING & 1 if in vocational training or university & 0.24 & 0.43 & 0.23 & 0.42 \\
\hline
\end{tabular}

Notes: The control group is constituted of respondents living in the region around Dresden, a dead spot of

Western TV reception. Reference group of RURAL and URBAN: cities with 2,001-50,000 inhabitants.

\section{Results and Robustness Tests}

In this section we present the results of our analysis. Subsequently, we provide several robustness tests.

\subsection{Results}

The parameter estimates of Equation (1) are presented in the upper part of Table 3. As mentioned above, we identify TV consumption using the Dresden region dummy. The estimated parameters for this dummy in the first-stage reduced-form estimation, Equation (3), are given in the lower part of Table 3. The Dresden region dummy is highly significant with a negative sign in all model specifications, providing support for the relevance of our instrument. 
Table 3: IV Estimation Results

\begin{tabular}{|c|c|c|c|c|c|c|}
\hline & \multicolumn{2}{|c|}{$\begin{array}{c}(1) \\
\text { IV Probit model }\end{array}$} & \multicolumn{2}{|c|}{$(2)$} & \multicolumn{2}{|c|}{$\begin{array}{c}\text { (3) } \\
\text { IV Poisson model }\end{array}$} \\
\hline \multicolumn{7}{|c|}{ SECOND STAGE REGRESSION } \\
\hline \multirow[t]{2}{*}{ Endogenous Variable } & \multicolumn{2}{|c|}{$\begin{array}{r}\text { CHILDREN } \\
\text { (dichotomous) }\end{array}$} & \multicolumn{2}{|c|}{ CHILDREN } & \multicolumn{2}{|c|}{ CHILDREN } \\
\hline & Coefficient & Standard Error & Coefficient & $\overline{\text { Standard Error }}$ & Coefficient & Standard Error \\
\hline TV & $-0.0745^{*}$ & 0.0387 & $-0.0904 * * *$ & 0.0292 & $-0.0738 * * *$ & 0.0254 \\
\hline AGE & $0.6682 * * *$ & 0.0619 & $0.5734 * * *$ & 0.0467 & $0.5032 * * *$ & 0.0410 \\
\hline AGE2 & $-0.0088 * * *$ & 0.0010 & $-0.0073 * * *$ & 0.0007 & $-0.0067 * * *$ & 0.0007 \\
\hline INCOME & $-0.0013^{*}$ & 0.0008 & $-0.0014^{* *}$ & 0.0006 & $-0.0008^{*}$ & 0.0004 \\
\hline INCOME2 & 0.0000 & 0.0000 & 0.0000 & 0.0000 & 0.0000 & 0.0000 \\
\hline PARTNER & $0.4498 * * *$ & 0.1065 & $0.3211^{* * *}$ & 0.0799 & $0.2105^{* * *}$ & 0.0556 \\
\hline MARRIED & $1.1367 * * *$ & 0.1007 & $0.9569 * * *$ & 0.0833 & $0.7545^{* * *}$ & 0.0778 \\
\hline RELIGIOUS & -0.0750 & 0.1486 & -0.0345 & 0.1151 & -0.0019 & 0.0840 \\
\hline RURAL & $-0.2229 *$ & 0.1342 & -0.1172 & 0.1049 & -0.0848 & 0.0813 \\
\hline URBAN & -0.0672 & 0.1053 & -0.0526 & 0.0802 & 0.0028 & 0.0550 \\
\hline EDUCATION & $-0.1273^{* *}$ & 0.0521 & $-0.0752 * *$ & 0.0381 & -0.0445 & 0.0308 \\
\hline TRAINING & -0.2840 & 0.3010 & -0.3840 & 0.2440 & $-1.2873 * * *$ & 0.4793 \\
\hline CONSTANT & $-9.2624 * *$ & 0.9351 & $-8.3433 * *$ & 0.7276 & $-8.6062 * * *$ & 0.6202 \\
\hline \multicolumn{7}{|c|}{ FIRST STAGE REDUCED FORM REGRESSION } \\
\hline Endogenous Variable & \multicolumn{2}{|c|}{ TV } & \multicolumn{2}{|c|}{ TV } & \multicolumn{2}{|c|}{$\mathrm{TV}$} \\
\hline DRESDEN REGION & $-2.3655^{* * *}$ & 0.0837 & $-2.3673^{* * *}$ & 0.0836 & $-2.3661^{* * *}$ & 0.0837 \\
\hline CONTROLS & \multicolumn{2}{|c|}{ Yes } & \multicolumn{2}{|l|}{ Yes } & \multicolumn{2}{|l|}{ Yes } \\
\hline Number of Obs. & \multicolumn{6}{|c|}{1,597} \\
\hline
\end{tabular}

Notes: Significance levels: ${ }^{*} p<0.10 ;{ }^{* *} p<0.05 ;{ }^{* * *} p<0.01$. The exogenous controls in the first-stage reducedform estimation are the same as in the second stage.

The first column of Table 3 sets out the results of the dichotomous IV probit estimates. In line with our hypothesis, even the likelihood of having children at all is negatively affected by TV consumption, as evidenced by the p-value of 0.054 . We find the same effect of TV consumption in the IV ordered probit and the IV poisson models, which, in addition, account for the number of children. The resulting parameter estimates for both models are negative and significant at the 1 percent level, with p-values of 0.002 and 0.004 , respectively. Hence, the negative effect of TV consumption is robust with respect to the different model specifications employed in our study. Furthermore, our results show that age, income, partnership, and marital status have the expected effects in all estimated models. 


\subsection{Robustness Tests}

Although the natural experiment described above supports a causal interpretation of our results, in this subsection we address several concerns, which might potentially weaken our conclusion, and employ additional data sets to demonstrate the robustness of our results. First, we discuss potential sample selection effects due to varying urbanization levels and unobserved differences regarding the impact of pronatalist social policies in rural and urban areas. Second, we additionally employ individual cross section data from the SOEP. Finally, we introduce aggregate level data from the statistical yearbook of the GDR. In this setting, the loss of individual level information on TV consumption and fertility is to some extent compensated by the panel nature of the data set. Repeated observations of fertility outcomes on the district level permit difference-in-difference estimation and taking unobserved time aspects and district fixed effects into account.

\section{Sample Effects}

Population density and the level of urbanization were important determinants of fertility levels in developed societies in the 20th century. The urbanization rate and population density of Dresden was above the GDR average. That is, respondents of the control group (living in the Dresden region) were less likely to live in small villages and more likely to live in big towns (see Table 2). Although this fact should generally decrease fertility levels in Dresden thereby leading to underestimated TV-effects in our empirical framework, one might argue, on the contrary, that one of the central elements of the GDR family policy reforms was to increase access to child care. Based on theoretical arguments one could expect that such policies particularly support women with modern values who want to reconcile work and family. Also in the GDR times, these women might have tended to be concentrated in cities. Therefore, we next restrict our analysis to larger cities in order to show that our results remain robust for potential selection bias concerning women living in Dresden. 
Table 4: Restricted Sample IV Estimation Results - Robustness I

\begin{tabular}{|c|c|c|c|c|c|c|}
\hline & \multicolumn{2}{|c|}{$\begin{array}{c}(1) \\
\text { IV Probit model }\end{array}$} & \multicolumn{2}{|c|}{$(2)$} & \multicolumn{2}{|c|}{$\begin{array}{c}\text { (3) } \\
\text { IV Poisson model }\end{array}$} \\
\hline \multicolumn{7}{|c|}{ SECOND STAGE REGRESSION } \\
\hline \multirow[t]{2}{*}{ Endogenous Variable } & \multicolumn{2}{|c|}{$\begin{array}{r}\text { CHILDREN } \\
\text { (dichotomous) }\end{array}$} & \multicolumn{2}{|c|}{ CHILDREN } & \multicolumn{2}{|c|}{ CHILDREN } \\
\hline & Coefficient & Standard Error & Coefficient & Standard Error & Coefficient & Standard Error \\
\hline TV & $-0.0953^{*}$ & 0.0541 & $-0.1155^{* * *}$ & 0.0427 & $-0.1007 * *$ & 0.0402 \\
\hline AGE & $0.6535^{* * *}$ & 0.1011 & $0.5122 * * *$ & 0.0742 & $0.4472 * * *$ & 0.0614 \\
\hline AGE2 & $-0.0083^{* * *}$ & 0.0017 & $-0.0060^{* * *}$ & 0.0012 & $-0.0057 * * *$ & 0.0010 \\
\hline INCOME & -0.0001 & 0.0012 & -0.0013 & 0.0010 & -0.0005 & 0.0008 \\
\hline INCOME2 & 0.0000 & 0.0000 & 0.0000 & 0.0000 & 0.0000 & 0.0000 \\
\hline PARTNER & $0.2970 *$ & 0.1608 & 0.1880 & 0.1268 & 0.1210 & 0.0909 \\
\hline MARRIED & $0.9182 * * *$ & 0.1563 & $0.8508 * * *$ & 0.1296 & $0.6375 * * *$ & 0.1081 \\
\hline RELIGIOUS & -0.1696 & 0.3076 & -0.1946 & 0.2438 & -0.1185 & 0.1616 \\
\hline EDUCATION & $-0.1793 *$ & 0.0799 & $-0.1319 * *$ & 0.0589 & $-0.0744 *$ & 0.0410 \\
\hline TRAINING & 0.0756 & 0.4640 & -0.4033 & 0.3857 & -1.3242 & 1.9784 \\
\hline CONSTANT & $-8.9442 * *$ & 1.5601 & $-7.0244^{* *}$ & 1.2035 & $-7.7716^{* * *}$ & 1.0034 \\
\hline \multicolumn{7}{|c|}{ FIRST STAGE REDUCED FORM REGRESSION } \\
\hline Endogenous Variable & \multicolumn{2}{|c|}{ TV } & \multicolumn{2}{|c|}{ TV } & \multicolumn{2}{|c|}{$\mathrm{TV}$} \\
\hline DRESDEN REGION & $-2.5879 * * *$ & 0.1401 & $-2.5893^{* * *}$ & 0.1400 & $-2.5872^{* * *}$ & 0.1402 \\
\hline CONTROLS & \multicolumn{2}{|c|}{ Yes } & \multicolumn{2}{|l|}{ Yes } & \multicolumn{2}{|l|}{ Yes } \\
\hline Number of Obs. & & & 58 & & & \\
\hline
\end{tabular}

Notes: Significance levels: ${ }^{*} p<0.10 ;{ }^{* *} p<0.05 ;{ }^{* * *} p<0.01$. The exogenous controls in the first-stage reducedform estimation are the same as in the second stage. The Sample is restricted to people living in cities with at least 100,000 inhabitants.

Table 4 presents results for our estimates where we have restricted our sample to people who live in cities with at least 100,000 inhabitants. As can be seen in Table 4, no matter which econometric model we estimate the parameter capturing the impact of watching West-German TV remains highly significant and negative. ${ }^{13}$

\section{Reduced form SOEP estimates}

In this subsection of the paper we prove the robustness of our results with respect to the data set employed. Therefore, we double check our results using the German Socio-Economic

13 Furthermore, we re-estimated all models using broader definitions of urban containing respondents living in cities with at least 10,000, 20,000, and 50,000 inhabitants. The results always remain negative and strongly significant and are available upon request. 
Panel (the SOEP), a representative household survey providing detailed information on many socioeconomic characteristics relevant for our undertaking. ${ }^{14}$

In June 1990, immediately after the collapse of the communist regime, the first SOEP survey was carried out in East Germany, the formerly communist part of Germany, where the natural experiment studied in this paper took place. ${ }^{15}$ We take advantage of this very first wave of the SOEP that provides detailed information on the socio-economic determinants in the former GDR. Since the data set, however, contains no information about TV consumption (not to mention TV consumption under the former communist regime) we rely on a reduced form estimation explaining the number of children born between 1972 and 1990 (the collapse of the communist regime) - the treatment period as described in section 3.3 - conditional on the region of living.

Our SOEP sample consists of 1,150 women aged $15-49^{16}$ living in the Eastern part of Germany in 1990 . About $11 \%$ of the respondents in the sample live in the region around Dresden and, hence, constitute our control group. ${ }^{17}$

14 The data used in this publication were made available by the SOEP at the German Institute for Economic Research (DIW), Berlin (Wagner et al., 2007). Socio-Economic Panel (SOEP), version 27, doi:10.5684/soep.v27.

15 From November 1989 onwards East Germans were allowed to move freely within the GDR and across borders. This fact, however, does not affect the results of our robustness check as long as outmigration towards the western part of Germany was driven by the same labor market related factors and not specific for the region around Dresden.

16 Our results are very robust with respect to different age restrictions on the sample. We re-estimated all models for women aged 15-65 and with no upper age limit. The results remained unchanged.

17 This exactly mirrors the share of the population living in the administrative region around Dresden. According to the Statistical Yearbooks of the GDR, about $10.5 \%$ of the population lived in this administrative area. 
Table 5: Variable Definition and Descriptive Statistics of Control Variables SOEP Wave 1990

- Robustness II

\begin{tabular}{|c|c|c|c|c|}
\hline Variable Definition & \multicolumn{4}{|c|}{ Summary Statistic } \\
\hline \multirow[t]{2}{*}{ Description } & \multicolumn{2}{|c|}{ Control group } & \multicolumn{2}{|c|}{ Treatment group } \\
\hline & Mean & Sd. & Mean & Sd. \\
\hline \multicolumn{5}{|l|}{ Endogenous Variables } \\
\hline Number of children born between 1972 and 1990 & 1.29 & 0.99 & 0.96 & 0.96 \\
\hline \multicolumn{5}{|l|}{ Exogenous Variables } \\
\hline AGE $\quad$ age in years & 33.47 & 7.26 & 33.60 & 8.29 \\
\hline INCOME monthly net income & 973.09 & 379.22 & 951.01 & 366.96 \\
\hline MARRIED 1 if respondent is married & 0.83 & 0.38 & 0.72 & 0.45 \\
\hline RELIGIOUS 1 if respondent is member of religious denomination & 0.32 & 0.47 & 0.31 & 0.46 \\
\hline EDUCATION 1 if respondent owns upper secondary school degree & 0.15 & 0.36 & 0.13 & 0.34 \\
\hline Number of Obs. & & & & \\
\hline
\end{tabular}

Notes: The control group is constituted of respondents living in the region around Dresden, a dead spot of Western TV reception.

The variable to be explained is the number of children born between 1972 and 1990 - the treatment period in our natural experiment. As expected, for the control group (women living in the region around Dresden) the share of respondents having no children is about $26 \%$ while the opposite holds for the treatment group (other regions) with about $41 \%$ of the respondents having no children. Our sample further contains information on control variables, such as age, income, partner status, religion, and educational status. Detailed variable definitions and descriptive statistics on exogenous variables are depicted in Table 5. Again, control and treatment group do not differ significantly with respect to the control variables employed. 
Table 6: Reduced Form Estimation Results Based on the SOEP Wave 1990 - Robustness II

\begin{tabular}{|c|c|c|c|c|c|c|}
\hline & \multicolumn{2}{|c|}{$\begin{array}{c}\text { (1) } \\
\text { Probit model }\end{array}$} & \multicolumn{2}{|c|}{$\begin{array}{c}(2) \\
\text { Ordered Probit model }\end{array}$} & \multicolumn{2}{|c|}{$\begin{array}{c}\text { (3) } \\
\text { Poisson model }\end{array}$} \\
\hline \multicolumn{7}{|c|}{ REDUCED FORM REGRESSION } \\
\hline \multirow[t]{2}{*}{ Endogenous Variable } & \multicolumn{2}{|c|}{$\begin{array}{r}\text { CHILDREN } \\
\text { (dichotomous) }\end{array}$} & \multicolumn{2}{|c|}{ CHILDREN } & \multicolumn{2}{|c|}{ CHILDREN } \\
\hline & Coefficient & Standard Error & Coefficient & Standard Error & Coefficient & Standard Error \\
\hline TV EFFECT & $-0.2859 * *$ & 0.1417 & $-0.2794 * * *$ & 0.1042 & $-0.1688 * * *$ & 0.0642 \\
\hline AGE & $0.7580 * * *$ & 0.0519 & $0.8399 * * *$ & 0.0505 & $0.7979 * * *$ & 0.0468 \\
\hline AGE2 & $-0.0113^{* * *}$ & 0.0008 & $-0.0125 * * *$ & 0.0007 & $-0.0118 * * *$ & 0.0007 \\
\hline INCOME & -0.0000 & 0.0004 & -0.0004 & 0.0003 & -0.0002 & 0.0002 \\
\hline INCOME2 & 0.0000 & 0.0000 & 0.0000 & 0.0000 & 0.0000 & 0.0000 \\
\hline MARRIED & $0.5368 * * *$ & 0.1061 & $0.4710^{* * *}$ & 0.0962 & $0.3648 * * *$ & 0.0835 \\
\hline RELIGIOUS & -0.0117 & 0.0941 & 0.0610 & 0.0784 & 0.0517 & 0.0541 \\
\hline EDUCATION & 0.1057 & 0.1305 & 0.0514 & 0.0941 & 0.0285 & 0.0613 \\
\hline CONSTANT & $-12.1405^{* * *}$ & 0.8473 & $-13.1555^{* * *}$ & 0.7968 & $-13.0924 * * *$ & 0.7490 \\
\hline Number of Obs. & \multicolumn{6}{|c|}{1,150} \\
\hline
\end{tabular}

Notes: Significance levels: ${ }^{*} p<0.10 ; * * p<0.05 ; * * * p<0.01$.

The reduced form parameter estimates are presented in Table 6. Again, we estimate different model specifications and find a negative and statistically significant effect of the TV effect dummy variable associated with the Dresden region. These results provide additional evidence that the structural estimates discussed in the previous section are robust and that the underlying data gathering process did not affect the results of our main regression presented in section 4.1.

\section{Aggregate level data}

As described above, the major contribution of our paper to the existing literature is that we provide empirical evidence at the individual level on the impact of watching West-German TV on fertility behavior, thereby identifying the direct causal effect of watching West-

German TV. We next address the concern that long term trends in different regions affect our results. The fact that respondents living in the Dresden region had no access to West-German TV might coincidentally be correlated with unobserved long term trends. 
Table 7: Variable Definition and Descriptive Statistics of the Statistical Yearbook of the GDR - Robustness III

\begin{tabular}{|c|c|c|c|c|c|}
\hline \multicolumn{2}{|c|}{ Variable Definition } & \multicolumn{4}{|c|}{ Summary Statistic } \\
\hline \multirow[t]{2}{*}{ Variable } & \multirow[t]{2}{*}{ Description } & \multicolumn{2}{|c|}{ Control group } & \multicolumn{2}{|c|}{ Treatment group } \\
\hline & & Mean & Sd. & Mean & Sd. \\
\hline \multicolumn{6}{|l|}{ Endogenous Variable } \\
\hline FERTILITY & $\begin{array}{l}\text { General fertility rate (number of } \\
\text { children born to mothers between } \\
15 \text { and } 44 \text { years of age per } 1000 \\
\text { women) }\end{array}$ & 69.73 & 8.84 & 72.43 & 14.18 \\
\hline \multicolumn{6}{|l|}{ Exogenous Variables } \\
\hline TV EFFECT & $\begin{array}{l}\text { Interaction of TREATMENT } \\
\text { PERIOD and TREATMENT } \\
\text { GROUP }\end{array}$ & 0 & 0 & 0.52 & 0.50 \\
\hline TREATMENT PERIOD & $\begin{array}{l}1 \text { from } 1972 \text { onwards (in the } \\
\text { baseline specification); } 0 \text { otherwise }\end{array}$ & 0.52 & 0.50 & 0.52 & 0.50 \\
\hline TREATMENT GROUP & $\begin{array}{l}1 \text { for all districts except for the } \\
\text { Dresden districts; } 0 \text { otherwise }\end{array}$ & 0 & 0 & 1 & 0 \\
\hline NEW FLATS BUILT & $\begin{array}{l}\text { number of new built flats per } 1000 \\
\text { inhabitants }\end{array}$ & 5.95 & 3.90 & 6.98 & 4.44 \\
\hline CHILD CARE & $\begin{array}{l}\text { number of child care places for } \\
\text { children between } 3 \text { and } 6 \text { years of } \\
\text { age per } 100 \text { inhabitants }\end{array}$ & 515.71 & 417.74 & 516.07 & 405.10 \\
\hline DIVORCES & $\begin{array}{l}\text { number of divorces per } 1000 \\
\text { inhabitants }\end{array}$ & 1.86 & 0.49 & 2.16 & 0.82 \\
\hline DENSITY & $\begin{array}{l}\text { population density defined as } \\
\text { people per square } \mathrm{km} \text { of land area }\end{array}$ & 274.06 & 6.24 & 340.18 & 680.99 \\
\hline DISTRICT FIX EFFECTS & Dummy variable for each district & - & - & - & - \\
\hline TIME FIX EFFECTS & Dummy variable for each year & - & - & - & - \\
\hline
\end{tabular}

Notes: The control group is constituted of observations from the Dresden district. Our data define a balanced panel from 1957 until 1987 for 15 districts. Altogether we have 450 observations.

Therefore, we employ aggregate level data from the statistical yearbook of the GDR and estimate a difference-in-difference reduced form model of the hypothesis discussed above. In this setting, we explain the absolute number of new born children per 1000 women at the district level, as defined in Table 7, using control variables such as the number of flats built, existing child care places, divorce rates and population density. While the first two control 
variables approximate the impact of pronatalist socialist social policies, divorce rates in our setting can be interpreted as measuring the development of social norms and the legal framework in which individual fertility decisions have to be made. Finally, population density controls for long term regional developments driven by economic growth and internal migration. Repeated observations of the Dresden region from 1957 until 1987 then act as control group for non-Dresden districts and, as discussed in section 3.2., the time period from 1972 onwards constitutes the treatment period which is defined by access to West-German TV almost everywhere in the GDR except for most areas of the Dresden region. However, since we do not directly observe TV consumption on the district level, the results obtained within this empirical framework can only be interpreted as reduced form estimates of the two equation model defined in section 3.1.

Table 7 presents descriptive statistics and variable definitions. ${ }^{18}$ Altogether, we observe district specific general fertility rates and control variables for all 15 GDR regions from 1957 until 1987. That is, in our basic specification we have 16 years of treatment and 15 years before treatment. $^{19}$

Table 8 gives the parameter estimates of the reduced form difference-in-difference estimator at the district level as previously discussed in this section. From model 1 on the left to model 5 on the right part of Table 8 we add additional control variables. Model 1 presents simple difference-in-difference mean estimates where the interaction between the treatment group

18 It is worth noting that even if there was a positive bias in official statistical publications of the GDR regime, for example regarding the achievements of social policies such as the number new flats built, that this does not affect our results as long as this measurement error or bias was systematic for the entire country which is very plausible in such a centralized state. And even if the level of this bias has varied over time, the two-way panel difference-in-difference specification presented below should not be affected if changes regarding the political climate can be modelled as a common trend among all districts.

19 As an additional robustness check we re-estimate our model defining different treatment periods starting from 1973, 1974 and 1975, respectively. By doing so, we account for the gradual character of political developments. The results remain unchanged and are available upon request. 
dummy and the treatment period dummy is interpreted as the reduced form estimate of the TV effect in the non-Dresden regions within the GDR. We find a statistically significant negative reduced form effect which becomes stronger if we add additional control variables moving to the right in Table 8. Our preferred specification is given in model 5 where we include year fixed effects as well as district fixed effects to control for time invariant unobserved heterogeneity beyond the variables already explicitly controlled for in the model. As can be seen in Table 8, all model specifications result in a strongly negative treatment effect supporting the robustness of the parameter estimates obtained from the IV-regressions based on individual cross section data. ${ }^{20}$

20 Although DIVORCES in our model acts as a proxy for social norms and the legal framework with regards to marriages and, for example, legal custody of the children, it could be argued that this variable actually reflects the individual decision to separate and, hence, might be endogenous while all other control variables such as flats built and child care places are more or less outcomes of the central planning process in a communist regime and, therefore, exogenous. That is why we re-estimate all models presented in Table 8 using only undoubtedly exogenous variables, all variables except for DIVORCES. All results remain unchanged and are available upon request. 
Table 8: Reduced form estimates at the aggregate district level - Robustness III

\begin{tabular}{|c|c|c|c|c|c|c|c|c|c|c|}
\hline & \multicolumn{2}{|l|}{$\begin{array}{l}(1) \\
\text { OLS }\end{array}$} & \multicolumn{2}{|l|}{$\begin{array}{l}(2) \\
\text { OLS }\end{array}$} & \multicolumn{2}{|l|}{$\begin{array}{l}\text { (3) } \\
\text { OLS }\end{array}$} & \multicolumn{2}{|c|}{$\begin{array}{c}\text { (4) } \\
\text { One way FE }\end{array}$} & \multicolumn{2}{|c|}{$\begin{array}{c}\text { (5) } \\
\text { Two way FE }\end{array}$} \\
\hline \multicolumn{11}{|l|}{ REDUCED FORM REGRESSION } \\
\hline \multirow[t]{2}{*}{ Endogenous Variable } & \multicolumn{10}{|c|}{ FERTILITY } \\
\hline & \multicolumn{2}{|c|}{ Coefficient Robust Std. Err. } & \multicolumn{2}{|c|}{ Coefficient Robust Std. Err. } & \multicolumn{2}{|c|}{ Coefficient Robust Std. Err. } & \multicolumn{2}{|c|}{ Coefficient Robust Std. Err. } & \multicolumn{2}{|c|}{ Coefficient Robust Std. Err } \\
\hline TV EFFECT & $-7.3371^{* * *}$ & 2.1620 & $-8.0033^{* * *}$ & 2.0242 & $-6.3433 * * *$ & 1.8720 & $-5.5703 * * *$ & 1.5641 & $-6.1100 * * *$ & 1.7159 \\
\hline TREATMENT PERIOD & $-13.6871^{* * *}$ & 1.9512 & $-4.6937 * *$ & 2.3772 & $-11.2346^{* * *}$ & 2.2202 & $-13.1968^{* * *}$ & 0.9086 & 70.7397 & 40.9485 \\
\hline TREATMENT GROUP & $6.4857 * * *$ & 1.7372 & $6.1958 * * *$ & 1.5929 & 1.3086 & 1.7176 & - & - & - & - \\
\hline FLATS BUILT & - & - & $0.9906^{* * *}$ & 0.2445 & $1.0421^{* * *}$ & 0.3442 & -0.1293 & 0.3009 & $-0.0523 *$ & 0.5149 \\
\hline CHILD CARE PLACES & - & - & $-0.0201 * * *$ & 0.0019 & $-0.0878 * * *$ & 0.0054 & $-0.0877 * * *$ & 0.0097 & -0.2071 & 0.1056 \\
\hline DIVORCES & - & - & -0.3053 & 1.2803 & $-14.0319 * * *$ & 3.8323 & $-11.9350^{* * *}$ & 2.9548 & $-11.5916^{* * *}$ & 2.9742 \\
\hline POPULATION DENSITY & & & $-0.0043 * * *$ & 0.0008 & $-0.0530 * * *$ & 0.0051 & $-0.2713^{*}$ & 0.1272 & -0.2338 & 0.0967 \\
\hline FLATS BUILT2 & - & - & - & - & $-0.0581^{* * *}$ & 0.0114 & -0.0241 & 0.0256 & $-0.0224 *$ & 0.0237 \\
\hline CHILD CARE2 & - & - & - & - & $0.0001^{* * *}$ & 0.0000 & $0.0001^{* * *}$ & 0.0000 & 0.0001 & 0.0001 \\
\hline DIVORCES2 & - & - & - & - & $2.4503 * * *$ & 0.7330 & $2.4934 * * *$ & 0.4924 & $1.8455^{*}$ & 0.4510 \\
\hline POPULATION DENSITY2 & & & & & $0.0000 * * *$ & 0.0000 & $0.0001 *$ & 0.0000 & 0.0000 & 0.0000 \\
\hline DISTRICT FIX EFFECTS & - & - & - & - & - & - & Yes & & Yes & \\
\hline TIME FIX EFFECTS & - & - & - & - & - & - & - & - & Yes & \\
\hline CONSTANT & $76.7933^{* * *}$ & 1.5372 & $78.4020^{* * *}$ & 1.9807 & $108.5715^{* * *}$ & 4.0086 & $164.9182^{* * *}$ & 31.1906 & $151.4539 * * *$ & 23.1487 \\
\hline R-squared & 0.5529 & & 0.6281 & & 0.778 & & & & 0.119 & \\
\hline Number of Obs. & & & & & 465 & & & & & \\
\hline
\end{tabular}

Notes: Significance levels: $* p<0.10 ;{ }^{* *} p<0.05 ; * * * p<0.01$. The suffix 2 indicates squared variables. 


\section{Conclusion}

This paper explores the effect of Western TV consumption on fertility behavior in the former GDR. In the developed world, isolating the impact of watching TV on behavior is usually complicated due to the fact that a suitable control group hardly exists. However, we are able to identify a causal relationship between Western TV consumption and fertility by exploiting a natural experiment that took place within the separated Germany. Contrary to the values and family role models promoted by the communist regime established in the eastern part of Germany, Western TV portrayed lifestyles in which children played only a small part; female characters had much fewer children or no children at all. Due to geographical reasons we can identify regions of the GDR that could not receive Western TV programs aired from the Federal Republic of Germany. Therefore, a natural variation of West German television exposure occurred, which enables us to instrument the consumption of Western TV programs in our empirical analysis.

We find robust empirical evidence that consumption of Western TV programs, which promoted smaller families and more hedonic values, significantly lowered fertility. From a more general perspective, this evidence suggests that, in addition to economic determinants, fertility decisions might also be affected by role models or information about other ways of life promoted by the media, factors that are usually ignored in economics. Hence, the classical investment and opportunity cost framework, which is still dominant in the economic profession, might only partly represent how fertility decisions are made. 


\section{References}

Becker, Anne. (2004). “Television, Disordered Eating, and Young Women in Fiji: Negotiating Body Image and Identity during Rapid Social Change.” Culture, Medicine,and Psychiatry 28: 533-559.

Becker, Gary S. (1960). “An Economic Analysis of Fertility”. In Becker, Gary S. (ed.): Demographic and Economic Change in Developed Countries. Princeton, NJ, Princeton University Press.

Becker, Gary S., Lewis, Gregg H. (1973). “On the Interaction between the Quantity and Quality of Children.” The Journal of Political Economy 81(2): S279-S288.

Brand, Jennie and Davis, Dwight (2011). "The Impact of College Educaion on Fertility: Evidence for Heterogeneous Effects.” Demography 48: 863-887.

Brewer, Mike, Ratcliffe, Anita and Smith, Sarah (2011). "Does Welfare Reform Affect Fertility? Evidence from the UK.” Journal of Population Economics 25 (1): 245-266.

Büning, Herbert and Trenkler, Götz (1994). „Nichtparametrische statistische Methoden.“ de Gruyter, Berlin.

Bursztyn, Leonardo and Davide Cantoni (forthcoming). “A Tear in the Iron Curtain: The Impact of Western Television on Consumption Behavior.” Review of Economics and Statistics. Doi:10.1162/REST_a_00522.

Cameron, Colin and Trivedi, Pravi (2005). "Microeconometrics. Methods and Applications.” Cambridge University Press, New York.

Chong, Alberto and Eliana, La Ferrara. (2009). ”Television and divorce: evidence from Brazilian novelas.” Journal of the European Economic Association 7(2-3): 458-468. 
Del Bono, Emilia, Weber, Andrea and Winter-Ebmer, Rudolf (2012). “Clash of career and family: fertility decisions after job displacement.” Journal of the European Economic Association 10(4): 659-683.

Fernández, Raquel and Fogli, Alessandra (2006). "Fertility: the role of culture and family experience.” Journal of the European Economic Association 4(2-3): 552-561.

Gerbner, George, Gross, Larry, Morgan, Michael, Signorielli, Nancy and Shanahan, James (2002). “Growing Up with Television: Cultivation Processes,” in Jennings, Bryant and Zillmann, Dolf (ed.): Media Effects: Advances in Theory and Research, Mah-wah, NJ: Erlbaum: 43-67.

Goldin, Claudia and Katz, Lawrence F. (2000). "Career and Marriage in the Age of the Pill.” The American Economic Review 90 (2): 461-465.

Heston, Alan, Summers, Robert and Aten, Bettina (2009). Penn World Table Version 6.3, Center for International Comparisons of Production, Income and Prices at the University of Pennsylvania.

Holbert, Lance R., Shah, Dhavan and Kwak, Nojin (2003). "Political Implications of PrimeTime Drama and Sitcom Use: Genres of Representation and Opinions Concerning Women’s Rights.” Journal of Communications 53: 45-60.

Hyll, Walter and Schneider, Lutz (2013). „The causal effect of watching TV on material aspirations: Evidence from the 'valley of the innocent'." Journal of Economic Behavior \& Organisation 86: 37-51.

Jensen, Robert and Oster, Emily (2009). “The Power of TV: Cable Television and Women's Status in India.” The Quarterly Journal of Economics 124(3): 1057-1094. 
Jensen, Robert (2012). “Do Labor Market Opportunities Affect Young Women’s Work and Family Decisions? Experimental Evidence From India.” The Quarterly Journal of Economics 127: 753-792.

Kern, Holger L., and Hainmueller, Jens (2009). “Opium for the masses: How foreign media can stabilize authoritarian regimes.” Political Analysis 17: 377-399.

Kalwij, Adriaan (2010). “The Impact of Family Policy Expenditure on Fertility in Western Europe.“ Demography 47(2): 503-519.

Kearney, Melissa S. and Levine, Phillip B. (2014). “Income Inequality and Early Nonmarital Childbearing.” Journal of Human Ressources 49(1): 1-31.

Küchenhoff, Erich (1975). “Die Darstellung der Frau und die Behandlung von Frauenfragen im Fernsehen. Eine empirische Untersuchung einer Forschungsgruppe der Universität Münster.“ Stuttgart (Schriftenreihe des Bundesministers für Jugend, Familie und Gesundheit, 34).

La Ferrara, Eliana, Chong, Alberto and Duryea, Suzanne (2012). "Soap Operas and Fertility: Evidence from Brazil." American Economic Journal: Applied Economics, 4(4): 1-31.

Lalive, Rafael and Zweimüller, Josef (2009). “How Does Parental Leave Affect Fertility and Return to Work? Evidence from two Natural Experiments.” The Quaterly Journal of Economics 124 (3): 1363-1402.

Li, Hongbin and Zhang, Junsen (2009). “Testing the External Effect of Household Behavior. The Case of the Demand for Children.” Journal of Human Resources 44(4): 890-915.

Milligan, Kevin (2005). "Subsidizing the Stork: New Evidence on Tax Incentives and Fertility.” The Review of Economics and Statistics 87(3): 539-555. 
Morgan, Michael and Rothschild, Nancy (1983). "Impact of the New Television Technology: Cable TV, Peers, and Sex-Role Cultivation in the Electronic Environment." Youth and Society 15: 33-50.

Mörk, Eva, Sjögren, Anna and Svaleryd, Helena (2013). "Childcare Costs and the Demand for Children - Evidence from a Nationwide Reform.” Journal of Population Economics 26(1): 33-65.

Pfau, Sebastian, Trültzsch Sascha, Kochanowski Katja, and Rüdinger Tanja (2010). "Von den Krügers bis zur Feuerwache. Vademekum der Familienserien des DDR-Fernsehens.” Leipziger Universitätsverlag, Leipzig.

Potter, Joseph E., Schmertmann, Carl P. and Cavenaghi, Suzana M. (2002). "Fertility and Development: Evidence From Brazil.” Demography 39(4): 739-761.

Shrum, L. J., Burroughs, James E. and Rindfleisch, Aric. (2005). “Television's Cultivation of Material Values.” Journal of Consumer Research 32(3): 473-479.

Socio-Economic Panel (SOEP) (2011). Data for years 1984-2010, version 27, SOEP, doi: 10.5684/soep.v27.

Trültzsch, Sascha (2009). “Kontextualisierte Medieninhaltsanalyse - Mit einem Beispiel zum Frauenbild in DDR-Familienserien.” VS Verlag für Sozialwissenschaften, Wiesbaden.

Wagner, Gert G., Frick, Joachim R. and Schupp, Jürgen (2007). "The German SocioEconomic Panel study (SOEP) - scope, evolution and enhancements." Schmollers Jahrbuch Journal of Applied Social Science Studies 127(1): 139-169. 
Weiderer, Monika (1994). "Das Frauen- und Männerbild im deutschen Fernsehen. Eine inhaltsanalytische Untersuchung der Sendungen mit Spielhandlung von ARD, ZDF und RTLplus.” Medienpsychologie 6, 15-34.

Weiderer, Monika and Faltenbacher, Christine (1994). "Das Frauen. und Männerbild in Familienserien des deutschen Fernsehens. Inhaltsanalytische Untersuchung und Folgerungen für die Pädagogik.” Medien und Erziehung 38: 208-214.

Wolle, Stefan (1998). „Die heile Welt der Diktatur: Alltag und Herrschaft in der DDR 19711989.“ Berlin, Links Verlag. 